\title{
Lethargic crab disease: multidisciplinary evidence supports a mycotic etiology
}

\author{
Walter A Boeger/ ${ }^{+}$, Marcio R Pie, Antonio 0 strensky*, Luciana Patella
}

Grupo Integrado de Aqüicultura e Estudos Ambientais (GIA), Departamento de Zoologia, *GIA, Departamento de Zootecnia, Universidade Federal do Paraná, Caixa Postal 19073, 81531-990 Curitiba, PR, Brasil

Although lethargic crab disease ( $L C D$ ) is causing massive mortalities in populations of the mangrove crab Ucides cordatus of Northeastern Brazil, the identity of its etiological agent was hitherto unknown. In this study we provide robust evidence suggesting that $L C D$ is caused by an anamorph Ascomycota (Fungi). We examined specimens of U. cordatus collected from stocks affected by LCD. Histological and TEM methods detected the presence of hyphae, conidia, and condiophores in several host tissues. Moreover, the abundance of fungal stages is negatively associated with crab health. Finally, DNA was isolated from the fungus and a region of its $18 S$ ribosomal gene was sequenced. Phylogenetic analyses not only confirm the diagnosis of the LCD fungus in crab tissues as an ascomycete, but also suggest a close relationship with members of the subphylum Pezizomycotina.

Key words: Ucides cordatus - mangrove crab - mass mortality - lethargic crab disease - Brazil

The mangrove crab, Ucides cordatus, plays a crucial role in a variety of ecosystem processes in its environment, such as nutrient cycling (Schories et al. 2003). Moreover, U. cordatus - regionally known as "caranguejo uçá" - is an important component in the economy of several underprivileged communities that depend on it for their subsistence. For example, 38\% of the households of 21 communities located around the estuary of the Rio Caeté (state of Pará, North Brazil) rely on the collection and commercialization of $U$. cordatus (Glaser 2003). Similar dependence on this natural resource is observed throughout much of North and Northeastern Brazil.

Beginning in 1998, massive mortalities of $U$. cordatus have been reported by crab-collectors ("catadores") and biologists throughout most of Northeastern Brazil, extending from the state of Ceará to the southern mangroves of the state of Bahia, and generating considerable concern with respect to the ensuing environmental and socioeconomic impacts (Nobrega \& Nishida 2003). There are no previous records of such high mortality levels, which may almost decimate local stocks. Interviews of crab-collectors by Nobrega and Nishida (2003) indicate up to $84 \%$ reduction in collection rates. Crabs in areas of high mortality share several common symptoms, such as lethargy, poor motor control, and inability to return to the upright position when turned upside down. Hence, an appropriate name for this pathology is lethargic crab disease (LCD).

Several potential etiological agents have been linked in unpublished accounts with LCD, including protists, fungi, bacteria, introduction of exotic metazoans, and

Financial support: Companhia de Desenvolvimento Industrial e de Recursos Minerais de Sergipe, CNPq

${ }^{+}$Corresponding author. E-mail: wboeger@ufpr.br

Received 13 October 2004

Accepted 7 March 2005 chemical poisoning. In some regions, LCD has been associated with sugar-cane cultures (Nobrega \& Nishida 2003), shrimp farming, oil prospection and extraction, and wood industry. However, despite substantial effort from several research groups in Brazil, the determination of the identity of the etiological agent of LCD has been elusive.

In this paper we provide evidence that LCD is caused by a fungus of the phylum Ascomycota. This conclusion is supported by both morphological (TEM and optical microscopy) and molecular methods. Moreover, preliminary evidence suggests that this fungus belongs to the subphylum Pezizomycotina.

\section{MATERIALSAND METHODS}

Mangrove crabs (U. cordatus) were collected from two states in Brazil, in locations where mortalities are known to have occurred: four mangrove complexes in the state of Sergipe and in the locality of Garapuá, Ilha de Tinharé, state of Bahia (Table I). The animals from Sergipe were captured by local crab-collectors and immediately submitted to a test designed to evaluate their health status (health index). This test was performed by turning each individual crab upside down and measuring the time (in seconds) it took to return to the upright position (Table II). When the animal was unable to recover after more than $30 \mathrm{~s}$, in a certain attempt (repetition), the value of 999 $\mathrm{s}$ was arbitrarily assigned. The mean of five repetitions of this procedure was used in the establishment of a health index.

Histology - The animals were sacrificed and samples of musculature, hepatopancreas, gills, thoracic ganglion, heart, posterior intestine, and gonads were removed, fixed in AFA, and preserved in etanol 70\%. Tissue samples were embeded in paraffin, sectioned at $5 \mu \mathrm{m}$, and stained in Hematoxilin-Eosin (HE), Periodic Acid Schiff (PAS), Mallory' or Grocott's Methanamine Silver (GMS). Permanent slides were analyzed with a microscope Olympus BX 51. Digital microphotographs were obtained with a Canon Powershot S50 camera connected to the microscope. The 
relative abundance of stages of the life cycle of the putative pathogenic organism was determined through examination of histological preparations and a subjective abundance scale of $0-5$. In this scale, 0 represents the absence and 5 indicates the widespread presence of these life cycle stages in the analyzed section.

Transmission electron microscopy - Samples of $2 \mathrm{~mm}^{3}$ of gills, heart and thoracic ganglion were removed and fixed in $2 \%$ glutaraldehyde for $3 \mathrm{~h}$, and preserved in a sucrose solution in cacodylate buffer. In the laboratory, the tissues were post-fixed in $2 \%$ osmium tetroxide for $4 \mathrm{~h}$, washed in cacodylate buffer, dehydrated in a crescent series of ethanol and embedded in resin (kit Embed $812^{\circledR}$ ). Ultra-thin sections (about $0.7 \mu \mathrm{m}$ ) were stained with uranil acetate and observed and photographed with the aid of a Jeol JEM 1200 EXII electron microscope of the Center of Electron Microscopy of the Universidade Federal do Paraná.

Molecular processing and analysis - Hemolymph samples from crabs with clear signs of illness were extracted with the help of a syringe inserted in through articulation membrane of their legs and fixed in ethanol $95 \%$. The process of extraction and isolation of DNA of the fungal spores (conidia) was based on the high resistance of their cell wall. Preliminary attempts to access the parasite's DNA were unsuccessful, rendering solely host's DNA - the parasite DNA remained within the spores of the pathogenic agent. Thus, samples of approximately $400 \mathrm{ml}$ of hemolymph, from each parasitized crab, were centrifuged at 14,000 rpm for $2 \mathrm{~min}$ and the supernatant was discarded. The precipitate was resuspended in $98 \mu \mathrm{l}$ of digestion buffer (Tris $50 \mathrm{mM}$ - pH 8.0, EDTA $100 \mathrm{mM}$, $0.5 \% \mathrm{SDS}$ ) with $2 \mu \mathrm{l}$ proteinase $\mathrm{K}$ and incubated at $50^{\circ} \mathrm{C}$ for $3 \mathrm{~h}$ for digesting of the host's tissue. Removal of host DNA was then accomplished using the initial part of the protocol for the kit EZ-DNA (Biosystems, Brasil) (i.e. until solubilization of the DNA molecules). The sample was, centrifuged at 14,000 rpm for $1 \mathrm{~min}$ and the supernatant, which contained DNA of the host, discarded.

The precipitate containing the parasite was resuspended in $500 \mu \mathrm{l}$ of double distilled water, centrifuged, and the supernatant discarded; this process was repeated three times to remove any trace of the host's DNA. The resulting precipitate was, once again, resuspended in 500 $\mu \mathrm{l}$ of double distilled water and submitted to cellular disruption by ultrasound using a ultrasound homogenizer Glues Parmer (Chicago, IL) at 5 X $50 \mathrm{KHz}$ for $30 \mathrm{~s}$. The extraction process was completed with the standard animal tissue protocol of the kit Dneasy (Qiagen, GmbH, Germany).

A fragment of the $18 \mathrm{~S}$ rDNA was amplified using the primers 1492R (5' - GGTTACCTTGTTACGACTT - 3') and T423F (5' - GCTTAATTTGACTCAACGC - 3') in $25 \mu 1$ reactions $\left(10.3 \mu \mathrm{lddH} \mathrm{d}_{2} \mathrm{O}, 25 \mathrm{mM} \mathrm{MgCl}, 10 \mathrm{mM}\right.$ dNTPs, 2,5 $\mu \mathrm{l}$ buffer, $2.5 \mathrm{U}$ Tth Polymerase (Biotools), $50 \mathrm{mM}$ of each primer, $3 \mu$ template) using the following program in a Mastercycler Personal Thermalcycler (Eppendorf): $9 \mathrm{~min}$ $\left(94^{\circ} \mathrm{C}\right) ; 32$ cycles $20 \mathrm{~s}\left(94^{\circ} \mathrm{C}\right)$ (denaturation), $40 \mathrm{~s}\left(56^{\circ} \mathrm{C}\right)$ (annealing), $1 \mathrm{~min}\left(72^{\circ} \mathrm{C}\right.$ ) (extension); $5 \mathrm{~min}\left(72^{\circ} \mathrm{C}\right.$ ) (final extension). PCR products were purified with the MinElute
PCR Purification kit (Qiagen, GmbH, Germany) and sequenced in an automatic sequencer ABI 3100 (Applied Biosystems). The fragment of the $18 \mathrm{~S}$ rDNA of the putative pathogenic organism of $U$. cordatus was submitted to the BLAST search system of the National Center for Biotechnology Information of the National Institutes of Health, (NCBI - GenBank) to determine a more inclusive taxonomic position. A tentative allocation of the pathogenic species into a narrower taxonomic unit (taxon) was attempted by performing phylogenetic analyses of the obtained sequences with sequences obtained in the GenBank of subunities of the more inclusive group and other sister taxa. These sequences were aligned with the program Clustalw (Thompson et al. 1994) and areas where the alignment was ambiguous were excluded.

Phylogenetic relationships were established by parsimony (weighted for transversions $-2: 1$ and unweighted), Neighboor Joining, and Bayesian inference reconstruction. The programs PAUP*4.0 b10 (Swofford 2003) and MrBayes (Huelsenbeck \& Ronquist 2001) were used according to the method of reconstruction employed. Support of branches was established through 500 bootstrap resampling replicates (Felsenstein 1985) and posterior probability scores (Huelsenbeck \& Ronquist 2001). Parsimony reconstruction was performed with 10 replicates $($ NREPS $=10)$ with random addition of taxa and up to 1000 cladograms retained in each replicate. The model of nucleotide evolution for Neighbor Joining method was determined using the program Modeltest (Posada \& Crandall 1998). Bayesian reconstruction was performed with 2.500.000 generations of 4 Markov chains, and the posterior probabilities of branches were obtained after 250.000 burn-in generations.

\section{RESULTS AND DISCUSSION}

Twelve crabs were captured in the state of Bahia and were used solely in the obtention of hemolymph. Twentyfour crabs, 4 females and 20 males, cephalothorax ranging from 4.5 to $7.5 \mathrm{~cm}$ wide (mean $=6.07 \mathrm{~cm}$ ), were captured from six locations within the states of Sergipe (Table I). The health status of these crabs varied from excellent to moribund (Table II), according to the health index applied (see above).

TABLE I

Location of the mangroves, date and number of Ucides cordatus collected

\begin{tabular}{llcr}
\hline Municipality & Coordinates & Date & N \\
\hline Garapuá (BA) & $13^{\circ} 28^{\prime} 26.1^{\prime \prime S}$ & Jan 3, 2004 & 12 \\
& $38^{\circ} 54^{\prime} 49.7^{\prime \prime} \mathrm{W}$ & & \\
Brejão (SE) & $10^{\circ} 31^{\prime} 56.9^{\prime \prime} \mathrm{S}$ & May 17, 2004 & 6 \\
& $36^{\circ} 29^{\prime} 27.1^{\prime \prime} \mathrm{W}$ & & \\
Brejão (SE) & $10^{\circ} 32^{\prime} 14.7^{\prime \prime S}$ & May 19, 2004 & 6 \\
& $36^{\circ} 30^{\prime} 44.9^{\prime \prime} \mathrm{W}$ & & \\
Areia Branca (SE) & $11^{\circ} 03^{\prime} 46.1^{\prime \prime S}$ & May 17-18, 2004 & 4 \\
& $37^{\circ} 08^{\prime} 17.8^{\prime \prime} \mathrm{W}$ & & \\
Crastro (SE) & $11^{\circ} 25^{\prime} 02.2^{\prime \prime} \mathrm{W}$ & May 19, 2004 & 5 \\
& $37^{\circ} 24^{\prime} 52.6^{\prime \prime} \mathrm{W}$ & & \\
Taiçoca de Fora (SE) & $11^{\circ} 25^{\prime} 02.1^{\prime \prime S}$ & May 21, 2004 & 4 \\
& $37^{\circ} 24^{\prime} 52.7^{\prime \prime} \mathrm{W}$ & & \\
\hline
\end{tabular}


TABLE II

Mean recovery time of Ucides cordatus and respective health index, and the number of crabs detected within each category

\begin{tabular}{cclc}
\hline Mean recovery time (in seconds) & Health index & Description & Number of crabs \\
\hline $0-2$ & 1 & Excellent & 7 \\
$2-3$ & 2 & Healthy & 4 \\
$3-5$ & 3 & Intermediary & 5 \\
$5-300$ & 4 & Compromised & 2 \\
$300-999$ & 5 & Moribund & 5 \\
\hline
\end{tabular}
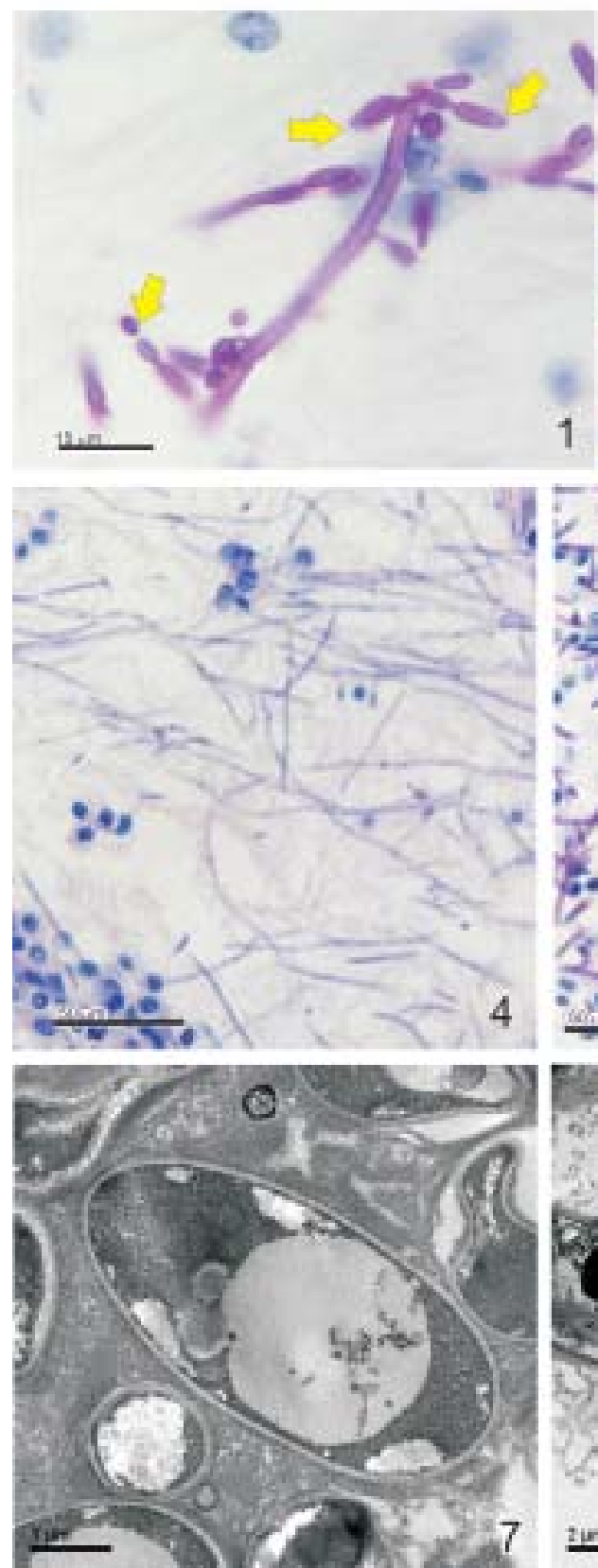
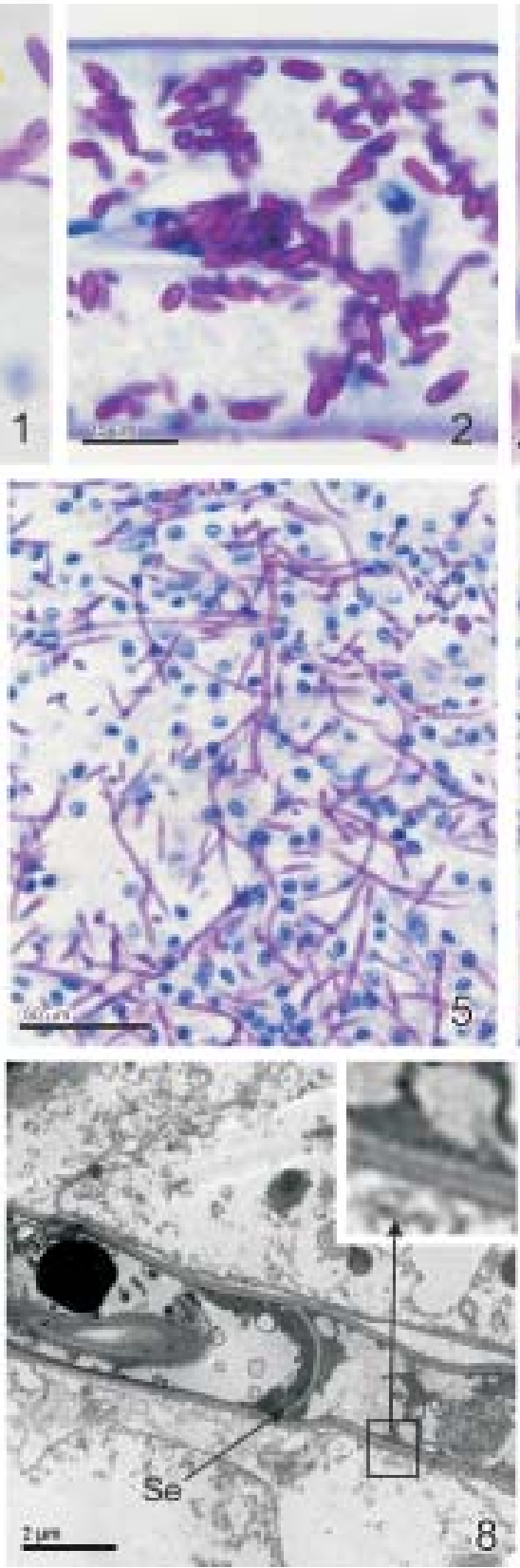
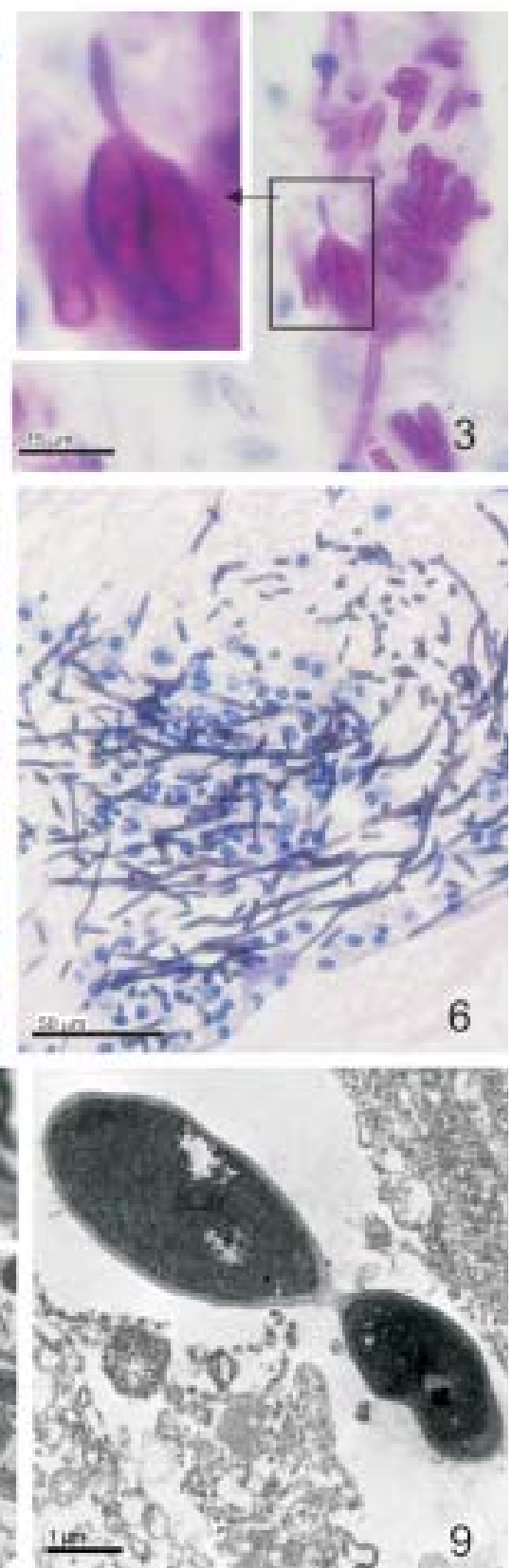

Ascomycota from Ucides cordatus. Fig. 1: light micrograph of a conidiophore in a histological section of the cardiac tissue (PAS). Fig. 2: light micrograph of transverse section of a gill lamella with numerous conidia in lacunae (PAS). Fig. 3: light micrograph of a conidium germinating in the cardiac tissue (PAS). Fig. 4: light micrograph of cardiac tissue parasitized by hyphae stained with H\&E. Fig. 5: light micrograph of cardiac tissue parasitized by hyphae stained with PAS (counter stained with H\&E). Fig. 6: Light micrograph of cardiac tissue parasitized by hyphae stained with GMS (counterstained with H\&E). Fig. 7: TEM micrograph of a conidium. Fig. 8: TEM micrograph of a hypha depicting septum (Se) and cell wall composed of two layers (detail). Fig. 9: TEM micrograph of two attached conidia attached (catenate). 
Histological analyses demonstrated that most crabs classified as moribund present a profusion of con-idiospores and hyphae (Figs 1-9) in several organs and tissues, especially in the heart, the thoracic ganglion, and the hemocele surrounding the hepatopancreas (Figs 10-18). Morphological, histochemical, and molecular analyses (see below) support the identification of the organism as a true fungus (Fungi). Both types of hyphae (somatic and conidiophores) and the conidiospores stain positively for Grocott's Methionine Stain and PAS, evidencing the chitinous composition of their cell walls (compare Figs 4-6).

Both conidiophores and somatic hyphae were detected mainly in the cardiac muscle and thoracic ganglion of moribund crabs (Figs 1-18) but were also observed, although less frequently, in the posterior intestine (Fig. 10), musculature of claw (Fig. 11), and locomotory pereiopod (Fig. 13) in crabs of the comparable impaired health status (health index).

Although sample size precludes adequate statistical analysis, the positive association observed in Figs 10-18 strongly supports the causal link between the LCD and the presence of conidia and hyphae. However, definitive liability of the fungus for this disease requires further experimentation to comply with Koch's postulates. Studies on the mode of action of the fungus are presently under way but preliminary data suggests that the most expressive damages are caused to the cardiac muscle and nervous systems. Conidia accumulate extensively in the hemocele surrounding the hepatopancreas and likely impair absorptive and digestive processes as well.

Somatic hyphae are hyaline, branched but apparently not reticulated, and depict septae which are visible under both light and electron microscopy (Fig. 8). Neither pores nor Woronin bodies could be seen in the septae. Cell wall is typically ascomycota, i.e. clearly composed of two layers (Fig. 8). Conidiogenous cells appear non-specific (sensu Kendrick \& Carmichel 1973), i.e. not specialized for the continuous production of conidia.

Conidia can be found within nodules or free in the tissue or hemocele. However, contrary to hyphae and conidiophores, conidia are present more extensively within tissues and organs, and in crabs classified under variable health status (Figs 10-18). Nodules are formed by a mass of agglutinated conidia (and sometimes hyphae) and hemocytes which are surrounded by hemocytes, often with deposition of melanin. Such nodules likely represent host cell reactions and are observed also in crabs classified as in excellent health status (Figs 1, 15, 18).

The conidia are ovate (Figs 1-3, 7,9), unicellular (amerospores) (Figs 7, 9), averaging 6.52 $\mu \mathrm{m}$ long (SD = $0.68)$ by $2.68 \mu \mathrm{m}$ wide $(\mathrm{SD}=0.39)$, and hyaline. Conidiogenesis is likely holoblastic (the wall of the conidiophore forms the conidium) (Fig. 9), catenate (may form chains) (Fig. 1, 9), and acropetale (older conidia near the base of the chain) (Figs 1,9). Conidia were observed germinating within the host's tissue (Fig. 3).

Thus, morphological characteristics suggest that the fungus from U. cordatus, responsible by the LCD, is a hyphomycete, a mitosporic fungus of the phylum Ascomycota. Fungal taxonomy is especially confused by the complexity of its life cycle and the difficulty of associating asexual cycles (anamorphs) and sexual cycles (teleomorphs) of a same species (Guarro et al. 1999). Most of the taxonomically diagnostic characters used in the higher taxonomy of fungi are teleomorphic features. Since the fungus detected on $U$. cordatus most likely represent
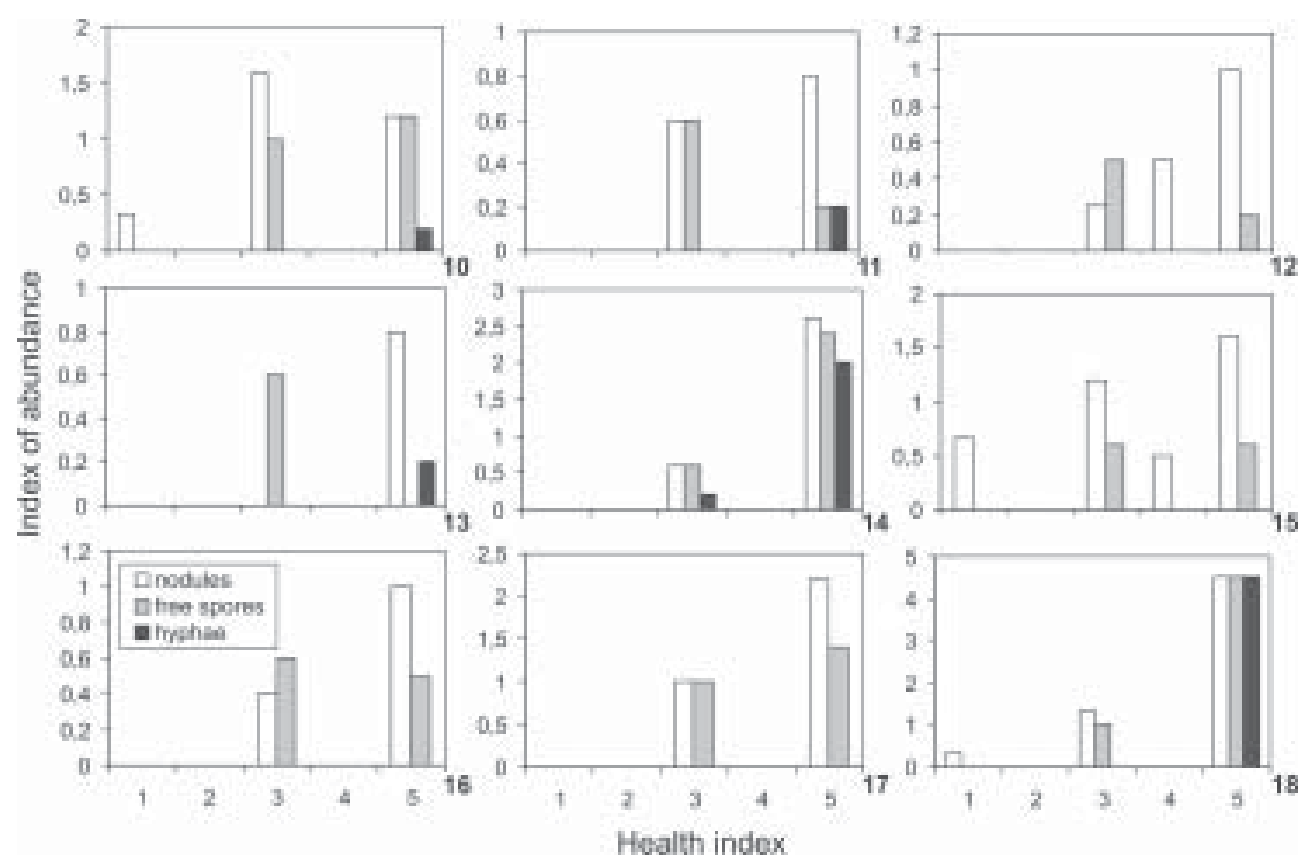

Abundance of forms of the ascomycete fungus in the tissues or organs according to the calculated health index of the specimens of Ucides cordatus analysed in the present study. Fig. 10: posterior intestine. Fig. 11: musculature of the claw. Fig. 12: abdominal musculature. Fig. 13: musculature of the pereiopod. Fig. 14: heart. Fig. 15: gills. Fig. 16: gonads. Fig. 17: hepatopancreas. Fig. 18: thoracic ganglion. 

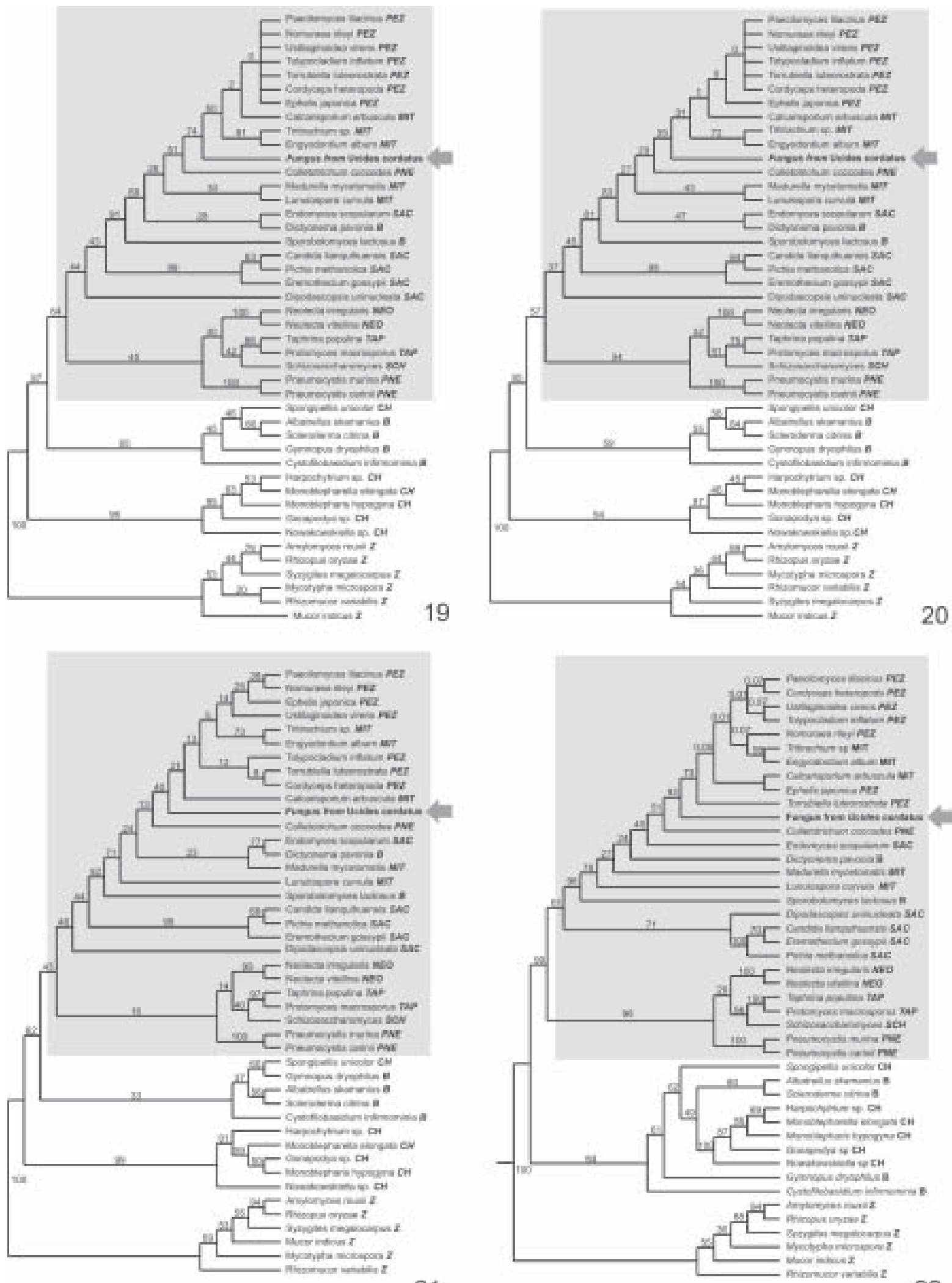

Phylogenetic relationships of the ascomycete of Ucides cordatus among representatives of distinct internal lineages of Fungi. Fig. 19: parsimony reconstruction (2:1 transversion to transition weighting). Fig. 20: parsimony reconstruction (equally weighted characters). Fig. 21: neighbour-joining reconstruction. Fig. 22: Bayesian reconstruction. Numbers above branches represent bootstrap values (Figs 19-21) or posterior probabilities (Fig. 22). Ascomycota - Neo: Neolectomycete; PEZ: Pezizomycotina; PNE: Pneumocystidomycete; SAC: Saccharomycotina; SCH: Schizosaccharomycetes; TAP: Taphrinomycetes; MIT: Mitosporic Ascomycota. B: Basidiomycetes, Z: Zygomycetes; $\mathrm{CH}$ : Chytridiomycetes. 
an anamorph, definition of its taxonomic position may be hindered.

A preliminary attempt to allocate the LCD anamorph in modern higher classification scheme of Fungi was made by sequencing a portion of its $18 \mathrm{~S}$ rDNA. The $560 \mathrm{bp}$ long sequence was submitted to the nucleotide-nucleotide BLAST (blastn) of the National Center for Biotechnology Information, National Institutes of Health, US (GenBank). The search supported the conclusions of the morphological and hystochemical analyses. The sequence of the fungus from $U$. cordatus is most similar to sequences of other Ascomycota.

\section{TABLE III}

Species of which sequences (with respective GenBank accession numbers) were used in the phylogenetic reconstructions used toward a preliminary identification of the pathogenic fungus of Ucides cordatus

\begin{tabular}{|c|c|}
\hline Species & Genbank \\
\hline Fungus from Ucides cordatus & AY943818 \\
\hline Neolecta irregularis & Z47721.1 \\
\hline Neolecta vitellina & Z27393.1 \\
\hline Paecilomyces lilacinus & AF548079.1 \\
\hline Nomuraea rileyi & AB 100361.1 \\
\hline Torrubiella luteorostrata & AY526469.2 \\
\hline Cordyceps heteropoda & $\mathrm{AB} 084157.1$ \\
\hline Ustilaginoidea virens & AB 162148.1 \\
\hline Ephelis japonica & AB114631.1 \\
\hline Tolypocladium inflatum & AB114224.1 \\
\hline Colletotrichum coccodes & AJ301957.1 \\
\hline Pneumocystis murina & AY532651.1 \\
\hline Pneumocystis carinii & L27658.1 \\
\hline Endomyces scopularum & AF267227.1 \\
\hline Dipodascopsis uninucleata & U00969.1 \\
\hline Eremothecium gossypii & AY046265.1 \\
\hline Candida llanquihuensis & $\mathrm{AB} 054541.1$ \\
\hline Pichia methanolica & AB018181.1 \\
\hline Schizosaccharomyces & AY046272.1 \\
\hline Protomyces macrosporus & D85143.1 \\
\hline Taphrina populina & D14165.1 \\
\hline Calcarisporium arbuscula & AY271796.1 \\
\hline Tritirachium sp. & AB 109761.1 \\
\hline Madurella mycetomatis & AF527811.1 \\
\hline Engyodontium album & AB 106650.1 \\
\hline Lunulospora curvula & AY357279.1 \\
\hline Dictyonema pavonia & U23541.1 \\
\hline Sporobolomyces lactosus & $\mathrm{AB} 021676.1$ \\
\hline Cystofilobasidium infirmominiatum & AB072226.1 \\
\hline Albatrellus skamanius & AF287829.1 \\
\hline Scleroderma citrina & AF026621.1 \\
\hline Gymnopus dryophilus & AY665779.1 \\
\hline Mycotypha microspora & AF 157148.1 \\
\hline Mucor indicus & AY054699.1 \\
\hline Amylomyces rouxii & AY054697.1 \\
\hline Rhizopus oryzae & AF113440.1 \\
\hline Rhizomucor variabilis & AF113435.1 \\
\hline Syzygites megalocarpus & AF157162.1 \\
\hline Spongipellis unicolor & M59760.1 \\
\hline Nowakowskiella sp. & AY635835.1 \\
\hline Gonapodya sp. & AF164330.1 \\
\hline Monoblepharella elongata & AF164335.1 \\
\hline Harpochytrium sp. & AF164332.1 \\
\hline
\end{tabular}

Thus, based on this result, 44 other sequences of species representative of other fungal phyla and Ascomycota were obtained from GenBank (Table III), aligned and used in the phylogenetic analyses. Areas where the alignment was ambiguous were excluded, remaining 461 positions.

All four methods of phylogenetic analysis, Bayesian inference, neighbor-joining, weighted and unweighted parsimony, placed the fungus of $U$. cordatus within a clade formed by Ascomycota species (Figs 19-22). This conclusion is further confirmed by the presence of several well-supported nodes between the fungus of $U$. cordatus and other phyla. Moreover, a closer inspection of the topologies obtained indicate that our sequence is closely related to the species of the subphylum Pezizomycotina. However, additional sequences including genes with faster rates of mutation are necessary to firmly establish the position of the fungus that causes LCD within the Ascomycota.

While several ascomycetes are known parasites of other arthropods, such as insects and arachnids (Murrin 1996), few species are reported from brachyuran crabs (see Johnson 1983, Rand 1996). Most of those species are considered opportunistic but some appear to be obligatory parasites. Trichomaris invadens Hibbits, Hughes, and Sparks, 1981, causes the Black Mat Syndrome in the Alaskan Tanner crabs, Chionectes bairdii Rathbun (Rand 1996) and is probably the only obligatory parasitic teleomorph of crabs. Few anamorphs are considered to cause primary infections in fish and shellfish. Among those, species of Fusarium account for extensive mortalities in the native and cultured crustaceans (Johnson 1983).

The species that parasitize $U$. cordatus, however, does not appear to belong to any of the anamorph genera documented from species of Brachyura. Definitive determination of the species of this ascomycete is uncertain due to the present status of fungal classification and knowledge on individual species biology (e.g. association between anamorphs and teleomorphs). This will certainly require isolation and culturing, in addition to analyses of additional gene sequences, as suggested above. Further, confirmation of the fungus species as the causative agent of LCD will also depend on cultured samples of the ascomycete as well as experimentation through artificial infections, in order to satisfy Koch's postulates. However, additional support for the mycotic etiology of this disease is continuously revealed. Analysis of crabs captured during recent mortality in the region of Caravelas, state of Bahia (February, 2005) has consistently detected the same fungal forms in internal organs and systems of animals depicting clinical signs of LCD.

\section{ACKNOWLEDGMENTS}

The following persons provided either field or laboratory support to this study: M Cardoso, G Castilho, R Pilchowsky, RT Vianna, and M Chammas. Advice from Jeffrey Shields, of the Virginia Institute of Marine Sciences, US, was fundamental for this study.

\section{REFERENCES}

Felsenstein J 1985. Confidence limits on phylogenies: an approach using the bootstrap. Evolution 39: 783-791. 
Garro J, Gene J, Stechigel AM 1999. Development in fungal taxonomy. Clin Microbiol Rev 12: 454-500.

Glaser M 2003. Interrelations between mangrove ecosystem, local economy and social sustainability in Caeté Estuary, North Brazil. Wetlands Ecol Manag 11: 265-272.

Huelsenbeck JP, Ronquist F 2001. MrBAYES: Bayesian inference of phylogenetic trees. Bioinformatics 17: 754-755.

Johnson PT 1983. Diseases caused by viruses, rickettsiae, bacteria, and fungi. In AJ Provenzano, The Biology of Crustacea, Vol. 6, Pathobiology, Academic Press, New York, p. 1-78.

Kendrick BW, Carmichel JW 1973. Hyphomycetes. In GC Ainsworth, FK Sparrow, AS Sussman (eds), The Fungi: an Advanced Treatise, Vol. IVA, A Taxonomic Review with Keys: Ascomycetes and Fungi Imperfecti, Academic Press, New York, p. 323-509.

Murrin F 1996. Fungi and insects. In DH Howard, JD Miller (eds), The Mycota. A Comprehensive Treatise on Fungi as Experimental Systems for Basic and Applied Research. VI. Human and Animals Relationships, Springer-Verlag Berlin, p. 366-368.

Nóbrega RR, Nishida AK 2003. Aspectos socioeconômicos e percepção ambiental dos catadores de caranguejo-uçá,
Ucides cordatus (L. 1763) (Decapoda, Brachyura) do estuário do rio Mamanguape, Nordeste do Brasil. Interciencia 28: 36-43.

Posada D, Crandall KA 1998. Modeltest: testing the model of DNA substitution. Bioinformatics 14: 917-918.

Rand TG 1996. Fungal diseases of fish and shellfish. In DH Howard, JD Miller (eds), The Mycota. A Comprehensive Treatise on Fungi as Experimental Systems for Basic and Applied Research. VI. Human and Animals Relationships. Springer-Verlag, Berlin, p. 297-313.

Schories D, Barletta-Bergan A, Barletta M, Krumme U, Mehlig U, Rademaker V 2003. The keystone role of leaf-removing crabs in mangrove forests of North Brazil. Wetlands Ecol Manag 11: 243-255.

Swofford DL 2003. PAUP*. Phylogenetic Analysis Using Parsimony (*and Other Methods). Version 4. Sinauer Associates, Sunderland, Massachusetts.

Thompson JD, Higgins DG, Gibson TJ 1994. CLUSTAL W: Improving the sensitivity of progressive multiple sequence alignment through sequence weighting, position-specific gap penalties and weight matrix choice. Nucl Acids Res 22: 46734680 . 
